\title{
Methadone-induced encephalopathy: a case series and literature review
}

\author{
Maryam Haghighi-Morad ${ }^{1}$, Zahra Naseri ${ }^{1}$, Nazila Jamshidi ${ }^{2}$, Hossein Hassanian-Moghaddam ${ }^{3,4^{*}}$ (D), \\ Nasim Zamani ${ }^{3,4}$ and Leila Ahmad-Molaei ${ }^{5}$
}

\begin{abstract}
Background: Accidental ingestion or consumption of supra-therapeutic doses of methadone can result in neurological sequelae in humans. We aimed to determine the neurological deficits of methadone-poisoned patients admitted to a referral poisoning hospital using brain magnetic resonance (MR) and diffusion weighted (DW) imaging.
\end{abstract}

Methods: In this retrospective study, brain MRIs of the patients admitted to our referral center due to methadone intoxication were reviewed. Methadone intoxication was confirmed based on history, congruent clinical presentation, and confirmatory urine analysis. Each patient had an MRI with Echo planar T1, T2, FLAIR, and DWI and apparent deficient coefficient (ADC) sequences without contrast media. Abnormalities were recorded and categorized based on their anatomic location and sequence.

Results: Ten patients with abnormal MRI findings were identified. Eight had acute- and two had delayed-onset encephalopathy. Imaging findings included bilateral confluent or patchy T2 and FLAIR high signal intensity in cerebral white matter, cerebellar involvement, and bilateral occipito-parietal cortex diffusion restriction in DWI. Internal capsule involvement was identified in two patients while abnormality in globus pallidus and head of caudate nuclei were reported in another. Bilateral cerebral symmetrical confluent white matter signal abnormality with sparing of subcortical U-fibers on T2 and FLAIR sequences were observed in both patients with delayed-onset encephalopathy.

Conclusions: Acute- and delayed-onset encephalopathies are two rare adverse events detected in methadoneintoxicated patients. Brain MRI findings can be helpful in detection of methadone-induced encephalopathy.

Keywords: Methadone, Acute encephalopathy, Delayed leukoencephalopathy, Magnetic resonance imaging

\section{Background}

Methadone is a synthetic opioid that is increasingly used as an analgesic and in maintenance therapy of opioidaddicted patients $[1,2]$. Accidental ingestion of methadone or consumption of its supra-therapeutic doses have been shown to cause multi-organ damage in both humans and animals [1, 3-5].

There have been several previous case reports describing acute-onset encephalopathy (AOE) and delayed-onset leukoencephalopathy (DOL) as adverse complications of

\footnotetext{
* Correspondence: hassanian@sbmu.ac.ir

${ }^{3}$ Social Determinants of Health Research Center, Shahid Beheshti University

of Medical Sciences, Tehran, Iran

${ }^{4}$ Department of Clinical Toxicology, Loghman Hakim Hospital, Shahid

Beheshti University of Medical Sciences, Tehran, Iran

Full list of author information is available at the end of the article
}

methadone intoxication [4-6]. AOE presents with MRI abnormalities within the first admission of the patient. DOL, however, manifests with abnormalities detected on MRI in patients who have initially responded to treatment (complete resolution of symptoms), but are then readmitted after a period of lucidity (usually days to weeks post the primary event) with neurological or psychiatric deterioration [7-10].

$\mathrm{AOE}$ is one of the severe neurologic complications of methadone intoxication, that has previously been associated with carbon monoxide and heroin toxicities $[7,8]$. To date, eight case reports have been published reporting AOE associated with methadone toxicity, ages ranging from 22month-old to 65 years old $[1,4,5,11-16]$. These cases have reported a range of neurologic complications, including 
restrictive diffusion throughout the cerebral gray matter, bilateral diffuse cerebellar edema or infarction, hippocampal and basal ganglia (globus pallidus), fluid-attenuated inversion recovery (FLAIR) intensities, absence of central intracranial blood flow, supra and infratentorial gray matter thickening, and non-enhancing T2 hyperintensities and restriction diffusion in the white matter of both hemispheres with sparing of subcortical $U$ fibers $[4,5,11-16]$.

DOL was first described in a 24-year-old patient who developed apathy and disorientation after the initial improvement from a mixed methadone-benzodiazepine poisoning [16]. Other case studies have reported a range of DOL symptoms, including disorientation, paranoid and bizarre behavior, and severe progressive cognitive decline with bilateral cerebral white matter hyperintensities. MRI changes in these case reports have included diffuse abnormal T2 and FLAIR signals in the corona radiate, centrum semiovale and subcortical white matter throughout all lobes, and signal abnormalities in temporomesial, substantia nigra, and basal ganglia $[6,8,9,12$, $13,17-21]$. The aim of our study was to identify and describe the pattern of neurological deficits and associated brain magnetic resonance imaging (MRI) changes in methadone-poisoned patients.

\section{Methods}

In this retrospective file audit, the clinical records of all patients admitted to our referral poisoning hospital with the diagnosis of methadone intoxication between May 2016 and March 2018 were reviewed. A total of 2930 cases were identified, of whom only 10 fulfilled the inclusion criteria.

\section{Definitions}

Methadone intoxication was defined based on history, clinical presentations of respiratory depression (opioid toxidrome) or loss of consciousness (LOC) responsive to administration of naloxone, as well as detection of methadone in urine analysis. The patients were classified into two subtypes: acute- and delayed-onset encephalopathy (AOE and DOL, respectively) based on clinical history. Patients with persistent neurological deficits in their first admission were categorized to have AOE based on their MRI changes. Those who had been discharged after either complete or partial recovery from acute intoxication, but then deteriorated with neurological signs or symptoms within several days or weeks necessitating readmission were considered to have DOL [7-9]. The most prevalent delayed symptoms included psychotic delirium, fluctuating state of consciousness, depression, apathy, and bizarre behaviors [9-13]. Complete knowledge of time courses and clinical presentation was a prerequisite in categorization of the patients. Imaging was performed due to persistent neurological deficits several days after admission or if there was re-occurrence of neurotoxicity after a lucid interval of at least 1 week.

\section{Inclusion criteria}

AOE: Patients who had been admitted due to methadone intoxication and had undergone imaging due to persistent neurological deficits were enrolled in $\mathrm{AOE}$ group.

DOL: Neurological deficits were defined as a deterioration of neurologic function leading to readmission within one to 3 weeks after discharge without any new toxic exposure. Patients fulfilling this criteria were enrolled into the DOL group.

\section{Exclusion criteria}

If methadone diagnosis was not confirmed after the review of the history, presentation, and urine analysis. Patients who had co-ingestions confirmed by urine analysis were also excluded (e.g. Alcohol). Any cases with possible intoxication, with a coingestants known to cause MRI complications (carbon monoxide [CO], methanol, cyanide, etc.) were excluded.

\section{Imaging}

Scans were performed by a $1.5-\mathrm{T}$ multi-planar MRI device. Echo planar T1 (TR: $591 \mathrm{~ms}$, TE: $15 \mathrm{~ms}$, Spatial Resolution: $6.2 \mathrm{~mm}$ slice thickness, FoV: $230 \mathrm{~mm} * 230$ $\mathrm{mm}$ ), T2 (TR: $4048 \mathrm{~ms}$, TE:90 ms, Spatial Resolution: FLAIR, diffusion weighted imaging (DWI) and apparent deficient coefficient (ADC) sequences without contrast media were performed. The scan time was $15 \mathrm{~min}$. All images were reviewed by a single radiologist experienced in MRI. Detected abnormalities were recorded and categorized based on their anatomic location and sequence. The areas with both restriction in DWI and low signal in abnormal diffusion restriction (ADC) were considered abnormal.

\section{Results}

Eight patients had a brain MRI performed during their first admission due to persistent neurological deficit despite active treatment (AOE group; Tables 1 and 2). This group included four children (aged 23 months to 16 years) who had accidentally ingested methadone. The other two had developed new neurological deficits days after the initial recovery from intoxication (DOL group; Table 3). All ten patients had abnormal findings on MRI.

\section{AOE group}

Seven patients in this group were male and median age was 23 years [range; 23 months to 33 years). Based on urine analysis, three cases had positive urine for other drugs. One had received benzodiazepine as a part of medical management. Other two were multi-opioid abusers, but had only overdosed on methadone. Imaging findings in this group included bilateral confluent or 
Table 1 Clinical characteristics of patients with AOE

\begin{tabular}{lllll}
\hline Patient number & Age/ Sex & Initial presentation & Urine toxicology & Time to imaging \\
\hline 1 & $13 \mathrm{yr}, \mathrm{F}$ & Cyanosis & Methadone & Day 5 \\
2 & $16 \mathrm{yr}, \mathrm{F}$ & Apnea & Methadone & Day 7 \\
3 & $23 \mathrm{mo}, \mathrm{M}$ & Cyanosis & Methadone, benzodiazepine & Day 5 \\
4 & $30 \mathrm{yr}, \mathrm{M}$ & Intoxication then witnessed apnea & Methadone & Day 2 \\
5 & $31 \mathrm{yr}, \mathrm{M}$ & Confusion then witnessed apnea & Methadone, opiate & Day 12 \\
6 & $32 \mathrm{yr}, \mathrm{F}$ & LOC & Methadone & Day 3 \\
7 & $33 \mathrm{yr}, \mathrm{M}$ & LOC & Methadone, opiate & Day 2 \\
8 & $5 \mathrm{yr}, \mathrm{M}$ & LOC & Methadone & Day 2 \\
\hline
\end{tabular}

patchy T2 and FLAIR high signal intensity areas in cerebral white matter in six (Fig. 1), cerebellar involvement in four (Fig. 2), and bilateral occipitoparietal cortex signal abnormality (low on $\mathrm{T} 1$ and high on T2) associated with diffusion restriction (confirmed with low signal intensity in ADC) in three cases (Fig. 3) and without restriction in one case. Internal capsule involvement was detected in two patients with hyper-signal corpus callosum in one. Abnormalities in the globus pallidus and the head of caudate nuclei were reported in only one patient. The MRIs were performed at 2- and 12-day intervals after initial presentation with methadone intoxication (defined as the primary toxic event).

\section{DOL group}

The two patients in this group were 47 and 49 years old and had a 9- and 18-day lucid interval, respectively, between the initial presentation and clinical relapse (Table 3). Confluent bilateral symmetrical cerebral white matter signal abnormality with sparing of subcortical U-fibers on T2 and FLAIR sequences were observed in both of these patients (Fig. 4).

\section{Discussion}

Methadone-induced encephalopathy is a rare event. To date, this phenomenon remains poorly characterized [4, 5 , 21]. The brain MRI changes reported in the literature are summarized in Table 4 and include: cerebellum

Table 2 Brain MRI findings in patients with AOE

\begin{tabular}{|c|c|c|c|c|c|c|c|c|}
\hline Number & Age/ Sex & $\begin{array}{l}\text { Bilateral cerebral } \\
\text { white matter T2 } \\
\text { and FLAIR } \\
\text { hyperintensity }\end{array}$ & $\begin{array}{l}\text { Bilateral cerebellar } \\
\text { white and gray matter } \\
\text { T2 and FLAIR } \\
\text { hyperintensity }\end{array}$ & $\begin{array}{l}\text { Bilateral parieto- } \\
\text { occipital T2 and FLAIR } \\
\text { hyperintensity (PRES } \\
\text { features) }\end{array}$ & $\begin{array}{l}\text { Internal capsule } \\
\text { involvement }\end{array}$ & $\begin{array}{l}\text { Other } \\
\text { structures }\end{array}$ & Infarction & Hemorrhage \\
\hline 1 & $13 \mathrm{yr}, \mathrm{F}$ & Yes & Yes & Yes & - & - & No & No \\
\hline 2 & $16 \mathrm{yr}, \mathrm{F}$ & Yes & - & - & - & - & No & No \\
\hline 3 & $23 \mathrm{mo}, \mathrm{M}$ & Yes & - & - & - & - & No & No \\
\hline 4 & $30 \mathrm{yr}, \mathrm{M}$ & - & Yes & $\begin{array}{l}\text { Yes } \\
\text { With restriction in DWI } \\
\text { and low signal in } A D C \\
\text { sequences }\end{array}$ & - & - & No & No \\
\hline 5 & $31 \mathrm{yr}, \mathrm{M}$ & Yes & - & - & Yes & $\begin{array}{l}\text { Splenium of } \\
\text { corpus } \\
\text { callosum }\end{array}$ & No & No \\
\hline 6 & $32 \mathrm{yr}, \mathrm{F}$ & - & - & $\begin{array}{l}\text { Yes } \\
\text { With restriction in DWI } \\
\text { and low signal in ADC } \\
\text { sequences }\end{array}$ & - & - & No & No \\
\hline 7 & $33 \mathrm{yr}, \mathrm{M}$ & Yes & - & - & $\begin{array}{l}\text { Yes with } \\
\text { restriction in } \\
\text { DWI and ADC } \\
\text { sequences }\end{array}$ & - & No & No \\
\hline 8 & $5 \mathrm{yr}, \mathrm{M}$ & - & Yes & $\begin{array}{l}\text { Yes } \\
\text { With restriction in DWI } \\
\text { and low signal in } A D C \\
\text { sequences }\end{array}$ & - & $\begin{array}{l}\text { Globus } \\
\text { pallidus and } \\
\text { caudate } \\
\text { nuclei }\end{array}$ & No & No \\
\hline
\end{tabular}


Table 3 Clinical characteristics and brain MRI findings of patients with DOL

\begin{tabular}{|c|c|c|c|c|c|c|c|}
\hline Number & Age/ Sex & $\begin{array}{l}\text { Toxic } \\
\text { agent }\end{array}$ & $\begin{array}{l}\text { Clinical } \\
\text { presentation in } \\
\text { relapse phase }\end{array}$ & $\begin{array}{l}\text { Time to relapse } \\
\text { after initial } \\
\text { intoxication }\end{array}$ & $\begin{array}{l}\text { Initial } \\
\text { imaging }\end{array}$ & Delayed phase brain MRI findings & $\begin{array}{l}\text { DWI and } \\
\text { ADC }\end{array}$ \\
\hline 9 & $47 \mathrm{yr}, \mathrm{M}$ & Methadone & $\begin{array}{l}\text { Disorientation, } \\
\text { seizure like } \\
\text { activity }\end{array}$ & 9 days & No & $\begin{array}{l}\text { Confluent bilateral symmetrical cerebral white matter } \\
\text { T2 and FLAIR hyperintensity with sparing of sub } \\
\text { cortical U-fibers }\end{array}$ & $\begin{array}{l}\text { No } \\
\text { restriction }\end{array}$ \\
\hline 10 & $49 \mathrm{yr}, \mathrm{M}$ & Methadone & Confusion & 18 days & No & $\begin{array}{l}\text { Confluent bilateral symmetrical cerebral white matter } \\
\text { T2 and FLAIR hyperintensity with sparing of sub } \\
\text { cortical U-fibers }\end{array}$ & $\begin{array}{l}\text { No } \\
\text { restriction }\end{array}$ \\
\hline
\end{tabular}

abnormalities $[1,4,10-14]$, bilateral cerebral white matter abnormalities $[4,5,11,12,14]$, signal changes in hippocampus [10], globus pallidus [13], and in a single case report in the head of caudate nuclei [4]. In addition, there is a single case report of a 2-year-old infant found to have cerebral white matter, cerebellar, and globus pallidus hypodensities based on computed tomography (CT) scan [22].

In our AOE patients, the most frequent MRI finding was bilateral confluent or patchy cerebral white matter hyperintensity $(n=5)$. Cerebellar abnormalities were detected in only three cases despite this was the most common observed abnormality in previous studies $[1,10,13]$. A consistent $(n=4)$ and new finding in these patients was bilateral parieto-occipital cortex T2 and FLAIR hyperintensity. This radiological finding has also been reported in patients with posterior reversible encephalopathy syndrome (PRES [23];). PRES has been reported as a consequence of or in conjunction with a variety of critical illness states including severe hypertension, hemolyticuremic syndrome, thrombocytopenic thrombotic purpura, and in association with drug toxicities such as cisplatin, cyclophosphamide, interferon [23-25], and opiates such as morphine $[26,27]$. In keeping with the findings in PRES, three of our patients had bilateral parieto-occipital cortex restriction in DWI which was confirmed by ADC sequence. Additionally, restriction was observed in one patient with internal capsule involvement (case 7). Restriction in bilateral cerebral white matter has previously been reported secondary to methadone toxicity $[4,11]$. One study suggested that "deep watershed infarct" resulted in the restriction imaging observed [11]. Given our observations and previous published reports, it can be postulated that the changes in AOE due to methadone could result in PRES.

We also had two patients who had internal capsule involvement. This finding is in accordance with previously published reports as a characteristic of heroin toxicity [28]. In our both patients, morphine and methadone were detected in urine analysis. Therefore, heroin use cannot be ruled out. Additional confirmatory testing for supplementary heroin metabolites would have been useful in these two individuals. However this was not available in our center. One of them (Case 5) demonstrated lesions in splenium of corpus callosum, a finding never reported before in either heroin or methadone intoxication. This finding may be a transient lesion of splenium and has been associated with various clinical conditions such as seizures, metabolic disturbances, infections, CNS malignancy, and drugs and toxins (antidepressants, antiepileptics, antipsychotics, chemotherapy agents, and pesticides) [15, 28-38]. We also had a single patient (case 8 ) who showed involvement of the globus pallidus and head of caudate nuclei. This finding has been observed
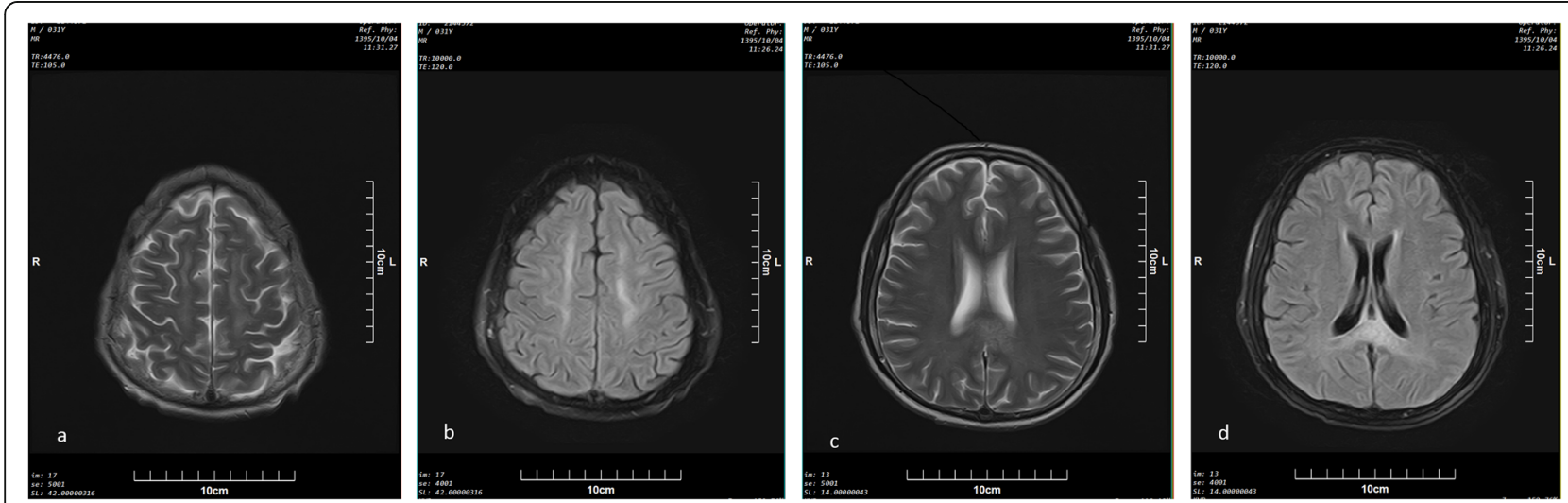

Fig. 1 Axial (a) T2 and (b) FLAIR sequences of a 31-year-old man (patient number 5), 12 days after presenting to emergency department with AOE symptoms, symmetric areas of hyperintensity in both centrum semiovale are seen. Axial (c) and (d) FLAIR sequences of the same patient at the mid ventricular level show hyperintensity in the splenium of corpus callosum 

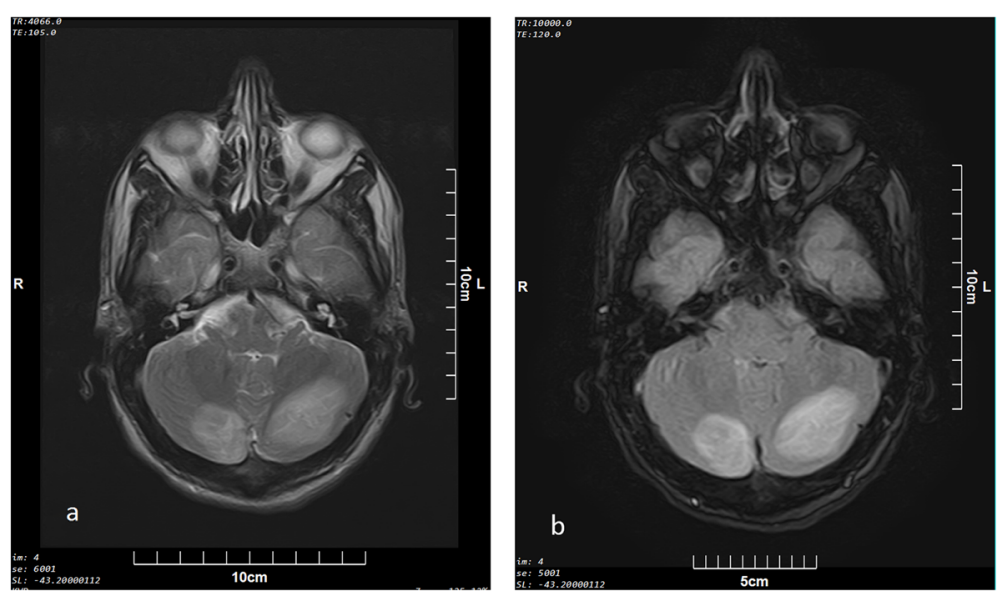

Fig. 2 Axial (a) T2 and (b) FLAIR sequences from posterior fossa at the level of fourth ventricle in a 30 year old male ( patient number 4) two days after primary symptoms of $\mathrm{AOE}$, high signal areas are seen in posterior part of cerebellum with gray and white mater involvement

in association with methadone toxicity [4, 13]. Previously, brain imaging changes associated with methadone intoxication were suggested to be as a consequence of hypoxic events secondary to overdose [12]. However, hypoxia-associated cerebral adverse effects on imaging seem to be only a result of prolonged hypoxia $[39,40]$. Majority of our patients did not have a persistent documented hypoxic insult. Brain neuroimaging was performed on admission, and before the worsening of patient's condition. Secondly, brain and cerebellar damage demonstrated at both diagnosis and follow-up showed a clear-cut prominent involvement of the subcortical white matter. In adulthood, hypoxic-ischemic insults usually result in watershed zone infarcts when mild to moderate, and affect the gray matter in the basal ganglia, thalami, cerebral cortex, cerebellum, and hippocampi when severe. Furthermore, severe insult generally includes a stage of diffuse cerebral edema with loss of differentiation between gray and white matter, a finding that was not noted in the patients reported.
Furthermore, acute and early subacute phases of hypoxia-induced encephalopathy primarily affect the basal ganglia, thalamus, and cortex [41]. We reported bilateral cerebral white matter and cerebellum abnormalities as the most common brain MRI finding.

To date, only 8 case reports evaluating 11 patients have been published reporting delayed-onset methadone-induced leukoencephalopathy $[6,10,16-20]$, summarized in Table 5. The most frequent imaging findings in case reports of patients with DOL is bilateral cerebral white matter T2 and FLAIR hyperintensity [6, $8,9,16,18,20]$ followed by corpus callosum $[9,16]$ and globus pallidus [8] involvement. This is in keeping with our observation of bilateral cerebral white matter hyperintensity. However, the findings in DOL group are not generalizable, as there were only two cases in this group, who also lacked imaging in their acute phase for comparison with the DOL phase imaging. Furthermore, during examination of DWI and ADC, no restriction was found in either case. Four patients have been described
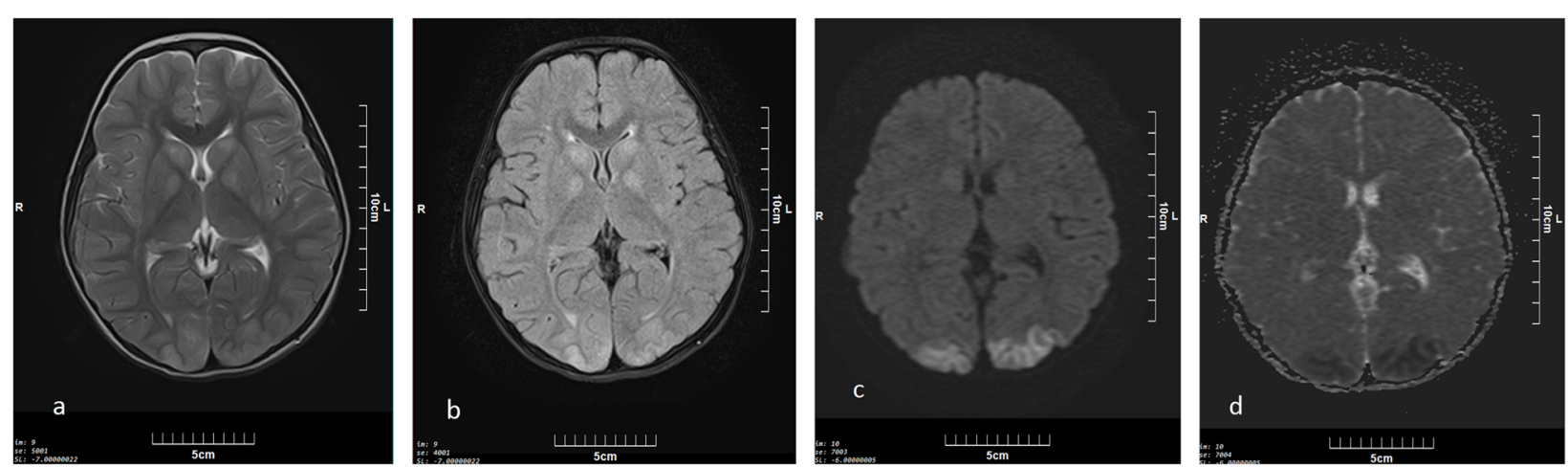

Fig. 3 Axial (a) T2 and (b) FLAIR sequences of a 5- year-old boy (patient number 8), two days after initial presentation of AOE, bilateral symmetric hyperintense areas are seen in basal ganglia (globus pallidus and head of caudate) in keeping with cortical and subcortical hyperintense areas in occipital lobes which has restricted in DWI (c) with low ADC signal (d) 

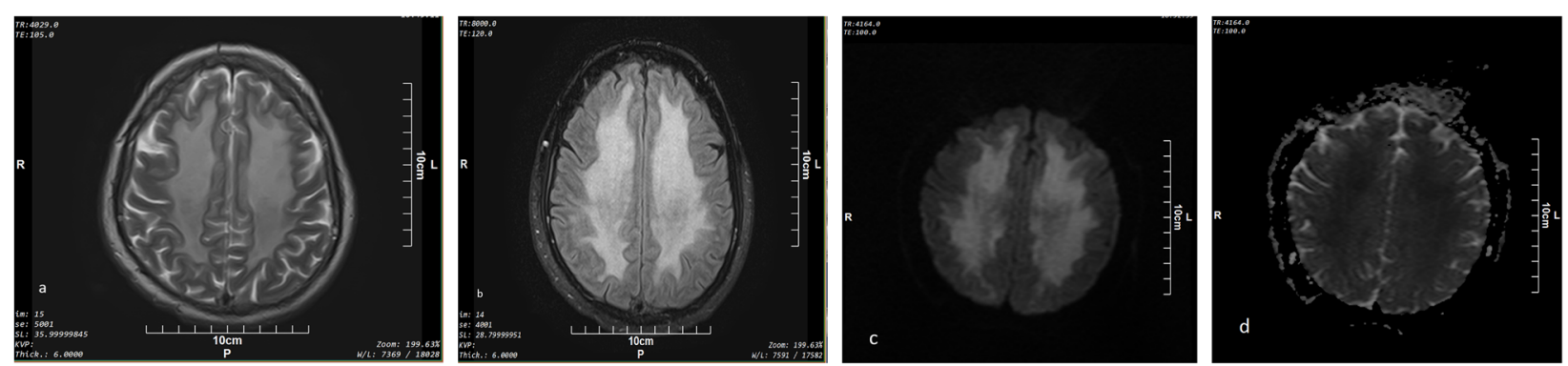

Fig. 4 Axial (a) T2 and (b) FLAIR sequences in a 47-year-old male with DOE (patient number 9) above the ventricular level show confluent bilateral symmetrical cerebral white mater hyperintensity with sparing of subcortical U-fibers. Axial (c) DWI and (d) ADC sequences also show T2 shine through phenomenon without any evidence of diffusion restriction

with restriction in DWI scans, although a correlation with ADC was not reported in them $[9,17,18,20]$. It is possible that the restrictions observed in these patients is related to $\mathrm{T} 2$ shine through, as this phenomenon has also been observed in our patients.

Almost all published case reports to date are in adult patients, except for a single case of 30-month-old infant. There are no previous publications on DOL due to other reasons (strangulation, $\mathrm{CO}$ poisoning, benzodiazepine overdose, etc.) in adults younger than 30 years [7]. Since both of our patients were also adults, it is possible that DOL is a phenomenon more common among adult patients. DOL has been previously suggested to be due to hypoxia $[6,16]$. However, given that neither of our patients had history of prolonged unconsciousness or respiratory depression, hypoxia as an etiology can be

Table 4 Summary of published case reports of $\mathrm{AOE}$

\begin{tabular}{|c|c|c|c|c|c|c|}
\hline Author(s) & Age/sex & Clinical presentation & $\begin{array}{l}\text { Clinical findings in } \\
\text { discharge }\end{array}$ & Lab Data & $\begin{array}{l}\text { Time to } \\
\text { imaging }\end{array}$ & MRI findings \\
\hline $\begin{array}{l}\text { Anselmo } \\
\text { M. Et al } \\
(2005) \\
{[10]}\end{array}$ & 3уо, $M$ & $\begin{array}{l}\text { LOC, irregular breathing, } \\
\text { low BP }\end{array}$ & Mild Ataxia & $\begin{array}{l}\text { Urine toxicology: } \\
\text { positive for methadone } \\
\text { after } 36 \mathrm{~h}\end{array}$ & Day 6 & $\begin{array}{l}\text { High T2 in cerebellar hemispheres } \\
\text { and hippocampus }\end{array}$ \\
\hline $\begin{array}{l}\text { Mills F. Et } \\
\text { al (2008) } \\
{[11]}\end{array}$ & 3yo, F & $\begin{array}{l}\text { LOC, hard breathing, } \\
\text { hypothermia }\end{array}$ & $\begin{array}{l}\text { Spastic dysplasia } \\
\text { and dystonia }\end{array}$ & $\begin{array}{l}\text { Urine toxicology: } \\
\text { positive for methadone }\end{array}$ & Day 2 & $\begin{array}{l}\text { FLAIR: damage to gray matter and } \\
\text { white matter of cerebellum with } \\
\text { marked swelling }\end{array}$ \\
\hline $\begin{array}{l}\text { Riascos R } \\
(2008) \\
{[12]}\end{array}$ & $22 \mathrm{mo}_{,-}$ & LOC & Brain death & $\begin{array}{l}\text { Urine toxicology: } \\
\text { positive for methadone, } \\
\text { acetaminophen and } \\
\text { salicylate }\end{array}$ & $\begin{array}{l}\text { In } \\
\text { admission } \\
\text { day }\end{array}$ & $\begin{array}{l}\text { Diffuse bilateral cerebellar infarction, } \\
\text { absence of central intra cranial blood } \\
\text { flow, supra and infra tentorial gray } \\
\text { matter thickening }\end{array}$ \\
\hline $\begin{array}{l}\text { Corré J. } \\
\text { Et al } \\
(2013) \\
{[13]}\end{array}$ & $29 y o, M$ & $\begin{array}{l}\text { LOC, hypothermia, } \\
\text { bradypnea }\end{array}$ & $\begin{array}{l}\text { Good recovery, } \\
\text { except persistent } \\
\text { renal failure and } \\
\text { kinetic cerebellar } \\
\text { syndrome }\end{array}$ & $\begin{array}{l}\text { Blood analysis was } \\
\text { positive for alcohol, } \\
\text { cannabis, methadone } \\
\text { (146 ng/ml), and } \\
\text { benzodiazepines }\end{array}$ & $\begin{array}{l}\text { At first day } \\
\text { of } \\
\text { admission. }\end{array}$ & $\begin{array}{l}\text { FLAIR and DWI: high in both } \\
\text { cerebellar and basal ganglia (globus } \\
\text { pallidus) }\end{array}$ \\
\hline $\begin{array}{l}\text { Metkees } \\
\text { M. Et al } \\
(2015) \\
{[14]}\end{array}$ & $15 y o, F$ & $\begin{array}{l}\text { LOC, hypothermia, } \\
\text { hypercapnia, HTN }\end{array}$ & Death & $\begin{array}{l}\text { Detailed history } \\
\text { revealed methadone } \\
\text { ingestion of unknown } \\
\text { quantity }\end{array}$ & $\begin{array}{l}\text { Not } \\
\text { mentioned }\end{array}$ & $\begin{array}{l}\text { T2 and DWI: high in white matter of } \\
\text { both hemisphere (sparing sub } \\
\text { cortical U-fibers and deep gray mat- } \\
\text { ter, cortical or cerebellar) }\end{array}$ \\
\hline $\begin{array}{l}\text { Cerase A. } \\
\text { Et al } \\
(2011)[4]\end{array}$ & 49yo, M & LOC & $\begin{array}{l}\text { Complete recovery } \\
\text { after } 3 \text { mo. }\end{array}$ & $\begin{array}{l}\text { Serum toxicology: } \\
\text { positive for methadone }\end{array}$ & $\begin{array}{l}\text { Not } \\
\text { mentioned }\end{array}$ & $\begin{array}{l}\mathrm{T} 2 \text { and FLAIR: high in white matter of } \\
\text { right cerebellum and deep gray and } \\
\text { white matter of both cerebral } \\
\text { hemispheres. }\end{array}$ \\
\hline $\begin{array}{l}\text { R.A. } \\
\text { Salgado } \\
\text { et al. } \\
\text { (2009) [5] }\end{array}$ & $65 y o, F$ & $\begin{array}{l}\text { Apathy, a catatonic state } \\
\text { with extreme rigidity, } \\
\text { reflexes in the upper limbs, } \\
\text { and a bilaterally positive } \\
\text { Babinski sign }\end{array}$ & $\begin{array}{l}\text { In the following } \\
\text { month, the patient } \\
\text { slowly recovered. }\end{array}$ & $\begin{array}{l}\text { Serum and urine } \\
\text { toxicology shows large } \\
\text { amount of methadone }\end{array}$ & Day 27 & $\begin{array}{l}\text { FLAIR and T2: symmetric signal } \\
\text { intensity abnormality in the deep } \\
\text { white matter of both cerebral } \\
\text { hemisphere with sparing of sub } \\
\text { cortical U-fibers without correspond- } \\
\text { ing diffusion restriction }\end{array}$ \\
\hline $\begin{array}{l}\text { Rando J. } \\
(2016)[1]\end{array}$ & $14 y o, M$ & $\begin{array}{l}\text { Hypothermia, HTN, } \\
\text { respiratory depression }\end{array}$ & $\begin{array}{l}\text { Aphasia, truncal } \\
\text { ataxia }\end{array}$ & $\begin{array}{l}\text { Serum toxicology: } \\
\text { positive for methadone }\end{array}$ & $\begin{array}{l}\text { In } \\
\text { admission } \\
\text { day }\end{array}$ & FLAIR: cereberallitis \\
\hline
\end{tabular}


Table 5 Summary of published works on DOL

\begin{tabular}{|c|c|c|c|c|c|c|c|c|}
\hline $\begin{array}{l}\text { Author(s) } \\
\text { year }\end{array}$ & Age/ Sex & Toxic agent & $\begin{array}{l}\text { Time to } \\
\text { relapse } \\
\text { after initial } \\
\text { intoxication }\end{array}$ & $\begin{array}{l}\text { Clinical } \\
\text { presentation in } \\
\text { relapse phase }\end{array}$ & $\begin{array}{l}\text { First imaging } \\
\text { findings }\end{array}$ & $\begin{array}{l}\text { Delayed phase } \\
\text { MRI findings }\end{array}$ & $\begin{array}{l}\text { DWI and } \mathrm{ADC} \\
\text { sequences findings }\end{array}$ & Prognosis \\
\hline $\begin{array}{l}\text { Ljungar B. } \\
\text { et al. } 2014 \\
\text { [17] }\end{array}$ & $34 \mathrm{yr}, \mathrm{M}$ & Methadone & 33 days & $\begin{array}{l}\text { Physical, } \\
\text { psychological } \\
\text { and cognitive } \\
\text { deterioration }\end{array}$ & $\begin{array}{l}\text { Cerebral } \\
\text { white matter } \\
\text { T2 } \\
\text { hyperintensity }\end{array}$ & $\begin{array}{l}\text { Cystic changes in } \\
\text { bilateral cerebral } \\
\text { white matter }\end{array}$ & $\begin{array}{l}\text { Hyperintensity in } \\
\text { DWI without ADC } \\
\text { confirmation }\end{array}$ & Recovery \\
\hline $\begin{array}{l}\text { Mittal M. } \\
\text { et al. } 2010 \\
\text { [6] }\end{array}$ & $38 \mathrm{yr}, \mathrm{M}$ & $\begin{array}{l}\text { Methadone, } \\
\text { benzodiazepine }\end{array}$ & 3 weeks & $\begin{array}{l}\text { Physical, } \\
\text { psychological } \\
\text { and behavioral } \\
\text { manifestations }\end{array}$ & No imaging & $\begin{array}{l}\text { Cerebral white } \\
\text { matter T2 } \\
\text { hyperintensity }\end{array}$ & No restriction & Partial recovery \\
\hline $\begin{array}{l}\text { Arciniegas } \\
2004 \text { [16] }\end{array}$ & $24 \mathrm{yr}, \mathrm{M}$ & $\begin{array}{l}\text { Methadone, } \\
\text { diazepam }\end{array}$ & $\begin{array}{l}\text { Not } \\
\text { mentioned }\end{array}$ & $\begin{array}{l}\text { Apathy, } \\
\text { disorientation }\end{array}$ & No imaging & $\begin{array}{l}\text { Cerebral white } \\
\text { matter and } \\
\text { corpus callosum } \\
\text { T2 hyperintensity }\end{array}$ & Not mentioned & Partial recovery \\
\hline \multirow[t]{2}{*}{$\begin{array}{l}\text { Torralba A- } \\
\text { Moron } \\
2016 \text { [8] }\end{array}$} & $42 \mathrm{yr}, \mathrm{M}$ & $\begin{array}{l}\text { Methadone, } \\
\text { alcohol, } \\
\text { benzodiazepine }\end{array}$ & 13 days & $\begin{array}{l}\text { Myoclonus, } \\
\text { fluctuated } \\
\text { consciousness, }\end{array}$ & $\begin{array}{l}\text { Normal CT } \\
\text { scan }\end{array}$ & $\begin{array}{l}\text { Cerebral white } \\
\text { matter and } \\
\text { globous pallidus } \\
\text { T2 hyperintensity }\end{array}$ & Not mentioned & $\begin{array}{l}\text { Lack of attention } \\
\text { and dysexecutive } \\
\text { and amnestic } \\
\text { abnormalities } \\
\text { persisted }\end{array}$ \\
\hline & $43 \mathrm{yr}, \mathrm{M}$ & Methadone & $\begin{array}{l}\text { Not } \\
\text { mentioned }\end{array}$ & $\begin{array}{l}\text { low level of } \\
\text { consciousness } \\
\text { and a } \\
\text { bradypnoea }\end{array}$ & $\begin{array}{l}\text { Not } \\
\text { mentioned }\end{array}$ & $\begin{array}{l}\text { Cerebral white } \\
\text { matter and } \\
\text { globous pallidus } \\
\text { T2 hyperintensity }\end{array}$ & Not mentioned & death \\
\hline $\begin{array}{l}\text { Zanin A. } \\
2010 \text { [19] }\end{array}$ & $30 \mathrm{mo}, \mathrm{F}$ & Methadone & 19 days & $\begin{array}{l}\text { Agitation, } \\
\text { slurred speech, } \\
\text { abnormal } \\
\text { movement }\end{array}$ & Normal & $\begin{array}{l}\text { Tempromesial, } \\
\text { Substantia Nigra } \\
\text { and basal ganglia }\end{array}$ & No restriction & $\begin{array}{l}\text { Recovery after } 2 \\
\text { month }\end{array}$ \\
\hline $\begin{array}{l}\text { Andrew } \\
\text { Meyer M. } \\
2013 \text { [20] }\end{array}$ & $43 \mathrm{yr}, \mathrm{F}$ & $\begin{array}{l}\text { Methadone, } \\
\text { diazepam }\end{array}$ & 3 weeks & $\begin{array}{l}\text { Forgetful\& } \\
\text { confused, social } \\
\text { withdrawal, lack } \\
\text { of hygiene }\end{array}$ & No imaging & $\begin{array}{l}\text { Cerebral white } \\
\text { matter } \mathrm{T} 2 \\
\text { hyperintensity }\end{array}$ & $\begin{array}{l}\text { Hyperintensity in } \\
\text { DWI without ADC } \\
\text { confirmation }\end{array}$ & Recovery \\
\hline $\begin{array}{l}\text { Carroll I. } \\
2012[9]\end{array}$ & $43 \mathrm{yr}, \mathrm{F}$ & $\begin{array}{l}\text { Alprazolam, } \\
\text { methadone }\end{array}$ & 33 days & $\begin{array}{l}\text { Apathy, } \\
\text { inappropriate } \\
\text { behavior }\end{array}$ & No imaging & $\begin{array}{l}\text { Cerebral white } \\
\text { matter and } \\
\text { corpus callosum } \\
\text { T2 hyperintensity }\end{array}$ & $\begin{array}{l}\text { Corpus Collosum } \\
\text { hyperintensity in } \\
\text { DWI without ADC } \\
\text { confirmation }\end{array}$ & $\begin{array}{l}\text { Full recovery after } 6 \\
\text { month }\end{array}$ \\
\hline \multirow[t]{3}{*}{$\begin{array}{l}\text { Shprecher } \\
\text { D. } 2008 \\
\text { [18] }\end{array}$} & $39 \mathrm{yr}, \mathrm{F}$ & $\begin{array}{l}\text { Methadone, } \\
\text { cocaine }\end{array}$ & 4 weeks & disorientation & No imaging & $\begin{array}{l}\text { Cerebral white } \\
\text { matter T2 } \\
\text { hyperintensity }\end{array}$ & $\begin{array}{l}\text { Hyperintensity in } \\
\text { DWI without ADC } \\
\text { confirmation }\end{array}$ & Partial recovery \\
\hline & $58 \mathrm{yr}, \mathrm{F}$ & methadone & 21 days & $\begin{array}{l}\text { Paranoid and } \\
\text { inappropriate } \\
\text { behavioral }\end{array}$ & No imaging & $\begin{array}{l}\text { Cerebral white } \\
\text { matter T2 } \\
\text { hyperintensity }\end{array}$ & Not mentioned & Partial recovery \\
\hline & $56 \mathrm{yr}, \mathrm{F}$ & $\begin{array}{l}\text { Methadone, } \\
\text { fentanyl, } \\
\text { benzodiazepine }\end{array}$ & 15 days & $\begin{array}{l}\text { Cognitive } \\
\text { deterioration }\end{array}$ & $\begin{array}{l}\text { Not } \\
\text { mentioned }\end{array}$ & $\begin{array}{l}\text { Cerebral white } \\
\text { matter T2 } \\
\text { hyperintensity }\end{array}$ & $\begin{array}{l}\text { Hyperintensity in } \\
\text { DWI without ADC } \\
\text { confirmation }\end{array}$ & Partial recovery \\
\hline
\end{tabular}

excluded. The lucid intervals of one to 5 weeks have been reported in earlier case reports [7], which was reinforced with our cases.

\section{Conclusion}

Methadone intoxication can result in a spectrum of encephalopathies ranging from AOE to DOL which can be diagnosed using MRI findings. Future studies on larger sample sizes are required to elucidate this association with its possible imaging findings. Our study is the first to demonstrate that MRI changes due to methadone intoxication can parallel those observed in PRES in both adults and children. Given that both heroin and morphine have been previously reported to present with changes suggestive of PRES, it is reasonable to extrapolate this to be an opioid class effect. In DOL, bilateral T2 and FLAIR white matter hyperintensity was the common finding. Therefore, in patients with a recent history of methadone intoxication who represent with relapsing neurological symptoms, DOL needs to be considered.

\section{Abbreviations}

ADC: Apparent deficient coefficient; AOE: Acute-onset encephalopathy; CNS: Central nervous system; CO: Carbon monoxide; CT: Computed tomography; DOL: Delayed-onset leukoencephalopathy; DWI: Diffusion 
weighted imaging; FLAIR: Fluid-attenuated inversion recovery; LOC: Loss of consciousness; MRI: Magnetic resonance imaging; PRES: Posterior reversible encephalopathy syndrome

\section{Acknowledgements}

This manuscript is based on the thesis of Dr. Naseri.

\section{Authors' contributions}

$\mathrm{HHM}$ is the guarantor of integrity of the entire study. NZ, MHM and HHM gave the study concepts and designed the study. NJ, MHM, and ZN did the literature research. HHM performed the data analysis. HHM performed the statistical analysis. ZN prepared the manuscript draft and NJ did edit the final manuscript. All co-authors approved final submitted manuscript. All authors read and approved the final manuscript.

\section{Funding}

Shahid Beheshti University of Medical Sciences fund this study with no role in the design of the study and collection, analysis, and interpretation of data and in writing the manuscript.

\section{Availability of data and materials}

All data generated or analysed during this study are included in this published article.

\section{Ethics approval and consent to participate}

This study was approved by the local ethics committee at Shahid Beheshti University of Medical Sciences (no 14911, IR.SBMU.REC.1397.011). Informed written consent was taken from all participants.

\section{Consent for publication}

Not applicable.

\section{Competing interests}

The authors declare that they have no competing interests.

\section{Author details}

'Department of Radiology, Loghman-Hakim Hospital, Shahid Beheshti University of Medical Sciences, Tehran, Iran. ${ }^{2}$ Drug Health Services, Sydney Local Health District, Sydney, NSW, Australia. ${ }^{3}$ Social Determinants of Health Research Center, Shahid Beheshti University of Medical Sciences, Tehran, Iran. ${ }^{4}$ Department of Clinical Toxicology, Loghman Hakim Hospital, Shahid Beheshti University of Medical Sciences, Tehran, Iran. ${ }^{5}$ Neuroscience Research Center, Shahid Beheshti University of Medical Sciences, Tehran, Iran.

Received: 27 September 2019 Accepted: 3 January 2020 Published online: 17 January 2020

\section{References}

1. Rando J, Szari S, Kumar G, Lingadevaru H. Methadone overdose causing acute cerebellitis and multi-organ damage. Am J Emerg Med. 2016;34(2): 343.e1-3.

2. Corkery JM, Schifano F, Ghodse AH, Oyefeso A. The effects of methadone and its role in fatalities. Hum Psychopharmacol. 2004;19(8):565-76 Available from: http://www.embase.com/search/results?subaction=viewrecord\&from= export\&id=L40028358\%0Ahttp://dx.doi.org/10.1002/hup.630\%0Ahttp://sfx. library.uu.nl/utrecht?sid=EMBASE\&issn=08856222\&id=doi:10.1002\%2Fhup.63 0\&atitle $=$ The+effects + of + methadone+and + its + role+in + fat

3. Aghabiklooei A, Edalatparvar M, Zamani N, Mostafazadeh B. Prognostic Factors in Acute Methadone Toxicity: A 5-Year Study. J Toxicol. 2014;2014:1-6.

4. Cerase A, Leonini S, Bellini M, Chianese G, Venturi C. Methadone-induced toxic leukoencephalopathy: Diagnosis and follow-up by magnetic resonance imaging including diffusion-weighted imaging and apparent diffusion coefficient maps. J Neuroimaging. 2011;21(3):283-6.

5. Salgado RA, Jorens PG, Baar I, Cras P, Hans G, Parizel PM. Methadoneinduced toxic leukoencephalopathy: MR imaging and MR proton spectroscopy findings. Am J Neuroradiol. 2010;31(3):565-6.

6. Mittal M, Wang Y, Reeves A, Newell K. Methadone-induced delayed posthypoxic encephalopathy: Clinical, radiological, and pathological findings. Case Rep Med. 2010;2010:22-6.
7. Zamora CA, Nauen D, Hynecek R, llica AT, Izbudak I, Sair HI, et al. Delayed posthypoxic leukoencephalopathy: A case series and review of the literature. Brain Behav. 2015;5(8):1-12.

8. Torralba-Morón Á, Ortiz-Imedio J, Morales-Conejo M, Ruiz-Morales J, GuerraVales JM. Delayed leukoencephalopathy: Three case reports and a literature review; 2016. p. 1-3. Available from: https://pdfs.semanticscholar.org/5631/ c70f6f7d7b69f0a9ab69f5401fa781dab799.pdf

9. Carroll I, Heritier Barras A-C, Dirren E, Burkhard PR, Horvath J. Delayed leukoencephalopathy after alprazolam and methadone overdose: A case report and review of the literature. Clin Neurol Neurosurg. 2012;114(6):8169. Available from:. https://doi.org/10.1016/j.clineuro.2011.12.052.

10. Anselmo M, Rainho AC, do Carmo Vale M, Estrada J, Valente R, Correia M, et al. Methadone intoxication in a child: Toxic encephalopathy? J Child Neurol. 2006;21(7):618-20.

11. Mills F, MacLennan SC, Devile CJ, Saunders DE. Severe cerebellitis following methadone poisoning. Pediatr Radiol. 2008;38(2):227-9.

12. Riascos R, Kumfa P, Rojas R, Cuellar H, Descartes F. Fatal methadone intoxication in a child. Emerg Radiol. 2008;15(1):67-70.

13. Corré J, Pillot J, Hilbert G. Methadone-Induced Toxic Brain Damage. Case Rep Radiol. 2013;2013:1-2.

14. Metkees M, Meesa IR, Srinivasan A. Methadone-induced acute toxic leukoencephalopathy. Pediatr Neurol. 2015;52(2):256-7. Available from:. https://doi.org/10.1016/j.pediatrneurol.2014.10.021.

15. Cho J-S, Ha S-W, Han Y-S, Park S-E, Hong K-M, Han J-H, et al. Mild Encephalopathy with Reversible Lesion in the Splenium of the Corpus Callosum and Bilateral Frontal White Matter. J Clin Neurol. 2007;3(1):53. Available from:. https://doi.org/10.3988/jcn.2007.3.1.53.

16. Arciniegas DB, Frey KL, Anderson CA, Brousseau KM, Harris SN. Amantadine for neurobehavioural deficits following delayed post-hypoxic encephalopathy. Brain Inj. 2004;18(12):1309-18 Available from: https://www. ncbi.nlm.nih.gov/pubmed/15666573.

17. Bileviciute-Ljungar I, Häglund V, Carlsson J, Von Heijne A. Clinical and radiological findings in methadone-induced delayed leukoencephalopathy. J Rehabil Med. 2014;46(8):828-30.

18. Shprecher DR, Flanigan KM, Smith AG, Smith SM, Schenkenberg T, Ph D, et al. Clinical and Diagnostic Features of Delayed Hypoxic. Low Extrem. 2008;20(4): 473-7.

19. Zanin A, Masiero S, Severino MS, Calderone M, Da Dalt L, Laverda AM. A delayed methadone encephalopathy: Clinical and neuroradiological findings. J Child Neurol. 2010;25(6):748-51.

20. Meyer MA. Delayed post-hypoxic leukoencephalopathy: case report with a review of disease pathophysiology. Neurol Int. 2013;5(3):13.

21. Li W, Li Q, Wang Y, Zhu J, Ye J, Yan X, et al. Methadone-induced Damage to White Matter Integrity in Methadone Maintenance Patients: A Longitudinal Self-control DTI Study. Sci Rep. 2016;6(January):1-8. Available from:. https:// doi.org/10.1038/srep19662

22. Hassanian-moghaddam H, Zamani N. An Overview on MethadoneIntoxicated Patients, vol. 3; 2016. p. 525-31.

23. Hobson EV, Craven I, Catrin BS. Posterior reversible encephalopathy syndrome: A truly treatable neurologic illness. Perit Dial Int. 2012;32(6):590-4.

24. Al-Sherif AH. Posterior Reversible Encephalopathy Syndrome (PRES): Restricted Diffusion does not Necessarily Mean Irreversibility. Polish J Radiol. 2015:80:210-6.

25. Rijkers K. An unusual case of posterior reversible encephalopathy syndrome in a patient being weaned from intrathecal morphine. Int Med Case Rep J. 2016;9:117-20

26. Eran A, Barak M. Combined General and Spinal Anesthesia with Intrathecal Morphine. 2009;108(2):609-612.

27. Lapat KD, Yousaf M, Joshi TR. Heroin-induced toxic leukoencephalopathy. Appl Radiol. 2016;45(3):36-7.

28. Keogh CF, Andrews GT, Forkheim KE, Graeb DA. Neuroimaging Features of Heroin Inhalation Toxicity: "Chasing the Dragon". Image (Rochester, NY). 2003;180(3):847-50.

29. Edwards TJ, Sherr EH, Barkovich AJ, Richards LJ. Clinical, Genetic and Imaging Findings Identify New Causes for Corpus Callosum Development Syndromes. Brain. 2014;137(6):1579-613 Available from: https://www. medscape.com/viewarticle/826563_1.

30. Naik K, Mali R, Kunam S, Saroja A. 'Wine Glass' sign in recurrent postpartum hypernatremic osmotic cerebral demyelination. Ann Indian Acad Neurol. 2013:16(1):106 Available from: http://www.annalsofian.org/text.asp?2 013/16/1/106/107719 
31. Tada H, Takanashi J, Barkovich AJ, Oba H, Maeda M, Tsukahara H, et al. Clinically mild encephalitis/encephalopathy with a reversible splenial lesion. Neurology. 2004;63(10):1854-8. Available from:. https://doi.org/10.1212/01. WNL.0000144274.12174.CB.

32. Garg R, Malhotra H, Sharma P, Vidhate M. Boomerang sign: Clinical significance of transient lesion in splenium of corpus callosum. Ann Indian Acad Neurol. 2012;15(2):151 Available from: http://www.annalsofian.org/text. asp?2012/15/2/151/95005.

33. Vyas $S$, Khandelwal N, Singh P, Gogoi D. Transient splenial lesion: Further experience with two cases. Indian J Radiol Imaging. 2010;20(4):254 Available from: http://www.ijri.org/text.asp?2010/20/4/254/73531.

34. Maeda M, Shiroyama T, Tsukahara H, Shimono T, Aoki S, Takeda K. Transient splenial lesion of the corpus callosum associated with antiepileptic drugs: evaluation by diffusion-weighted MR imaging. Eur Radiol. 2003;13(8):1902-6. Available from: https://doi.org/10.1007/s00330-002-1679-5.

35. Starkey J, Kobayashi N, Numaguchi Y, Moritani T. Cytotoxic Lesions of the Corpus Callosum That Show Restricted Diffusion: Mechanisms, Causes, and Manifestations. RadioGraphics. 2017;37(2):562-76. Available from: https://doi. org/10.1148/rg.2017160085.

36. Hornik A, Rodriguez Porcel FJ, Agha C, Flaster M, Morales Vidal S, Schneck $\mathrm{MJ}$, et al. Central and Extrapontine Myelinolysis Affecting the Brain and Spinal Cord. An Unusual Presentation of Pancreatic Encephalopathy. Front Neurol. 2012;3. Available from:. https://doi.org/10.3389/fneur.2012.00135/ abstract.

37. Loh Y. Restricted Diffusion of the Splenium in Acute Wernicke's Encephalopathy. J Neuroimaging. 2005;15(4):373-5. Available from:. https:// doi.org/10.1177/1051228405279037.

38. Kimura K, Fuchigami T, Ishii W, Imai Y, Tanabe S, et al. Mumps-virusassociated clinically mild encephalopathy with a reversible splenial lesion. Int J Clin Pediatr. 2012;1(4-5):124-8.

39. Weiss N, Galanaud D, Carpentier A, Naccache L, Puybasset L. Clinical review: Prognostic value of magnetic resonance imaging in acute brain injury and coma. Crit Care. 2007:11(5):1-12.

40. Heinz UE, Rollnik JD. Outcome and prognosis of hypoxic brain damage patients undergoing neurological early rehabilitation Neurology. BMC Res Notes. 2015;8(1):1-11.

41. Haaga JR, Boll DT. CT and MRI of the whole body. 6th ed; 1994. p. 577-8.

\section{Publisher's Note}

Springer Nature remains neutral with regard to jurisdictional claims in published maps and institutional affiliations.

Ready to submit your research? Choose BMC and benefit from:

- fast, convenient online submission

- thorough peer review by experienced researchers in your field

- rapid publication on acceptance

- support for research data, including large and complex data types

- gold Open Access which fosters wider collaboration and increased citations

- maximum visibility for your research: over $100 \mathrm{M}$ website views per year

At BMC, research is always in progress.

Learn more biomedcentral.com/submissions 